\title{
XLIII. On the real difference between the specific gravity of the human body and sea water
}

\section{Knight Spencer Esq.}

To cite this article: Knight Spencer Esq. (1818) XLIII. On the real difference between the specific gravity of the human body and sea water , Philosophical Magazine Series 1, 52:246, 282-283, DOI: $10.1080 / 14786441808652047$

To link to this article: http://dx.doi.org/10.1080/14786441808652047

册 Published online: 23 Jul 2009.

Submit your article to this journal $\sqsubset \pi$

Џ Article views: 2

Q View related articles $₫$ 


\section{Specific Gravity of the Human Body and Sea Water.}

main, a second and a third are dispatched for intelligence, who return and inform their associates; who, finding how the lands lie, depart from the body, taking possession of their domains, and wishing those behind good morning.

Gavin Inglis.

XLIII. On the real Difference letween the specific Gravity of the Human Body and Sea Water. By KNIGHT SPENCER, Esq.

\section{To Mr. Tilloch.}

SIR,- $\mathbf{I}_{\mathrm{N}}$ September 1815, you did me the favour to insert in your Magazine the result of an experiment which I had made with a view to ascertain how much the human body is specifcally lighter than sea-water; and, in answering your question respecting the same in the month of November of that year, I promised to repeat the experiment, with this difference, that I would make it in my usual dress, instead of being naked, the intention of which was, to ascertain what greater degree of danger (if any) would in consequence be incurred, either in the case of falling overboard, or in plunging into the sea without the delay of undressing, to prevent a fellow-creature from drowning, - and, generally speaking, to induce that fair degree of confidence which the knowledge of the real difference between the specific gravity of the human body and sea-water ought to inspire.

Circumstances have, until the present autumu, prevented me fulfilling my promise. I have now to state, that in August last I took the opportunity of a smooth sea for my experiment; and, in addition to my usual clotling (which weighed five pounds) I borrowed from the guide who attends the machines, a pair of heavy shoes with much iron about them, weighing three pounds and a half; and with flints in each hand weighing together six pounds two ounces, being altogether fourteen pounds ten ounces avoirdupois, I threw myself upon my back in the water, and floated upon the surface without the smallest motion whatever, so much at my ease as to converse with my friends on the beach, and with the toes of the heavy shoes just visible above the surface.

If the fact established by this experiment were more generally known, I think it could not fail to induce many timid persons to become expert swimmers, who are now afraid to venture into the sea at all.

Before 1 close this letter, pernit me, Sir, to state another fact, which cannot fail to give confidence to those who are learning to 
swim-and all young men, both for their own safety and the welfare of society, ought to learn this pleasing and healthy art.

At the time I was about to make my experiment, $I$ observed four boys take a boat, go into deep water, undress, and plunge in one after the other, range themselves in a line, and actually play a game ar leap-frog for at least a quarter of a mile. The last boy, swimming to the boy immediately before him, placed his hands on his shoulders, popped him under water, and then swam to the next; the boy who was popped under water, on rising, swam to the boy immediately before him, popped him under in his turn, and so on till they reached the shore.

I assure you, sir, that Captain Shandy, when carrying on the siege of Dendermonde, did not feel a stronger desire to have a pull at Corporal Trim's smoking mortars, than I did to make one with the boys at leap frog.

Surry Institution, October 8th, 1818. I am, sir,

Your obedient servant, Knight Spencer.

P.S. I omitted to state that I swam out into deep water, without the flints, and found no other inconvenience than a slight impediment to my progress from the drag of the laps of my coat.

XLIV. Hungarian Agriculture, and Improvements in the Management of Sheep and Cattle, as practised on the Estate of Graf' HunYadr, at Urmeny, in Lower Hungary*.

$\mathbf{W}_{\mathrm{x}}$

E proceeded to visit one of the Graf's farms, called Keszi. A large collection of peasants, with their cattle and ploughs, were at work on one part of it. The system here adopted is nearly the common agriculture of the country, the usual succession of crops being,

Ist year, wheat and rye, sown in winter.

$2 d$ year, grain of various sorts, sown in spring.

$3 d$ year, fallow.

4 th year, winter grain.

5 th year, spring grain.

6th year, fallow, with manure and good dunging, and so on, a simple fallow every third, and manuring every sixth year.

Maize is one of the most productive crops. It is planted in April, and cut in September or October, yielding thirty-fold, whilst other crops yield not more than ten-fold at the utmost.

Turnips have been fairly tried without success, on account of the dryness which usually prevails during the summer months.

The land is ploughed very shallow, seldom above three inches,

* From Dr. Bright's Trarcis. 